\title{
Diversity of new root nodule bacteria from Erythrina velutina Willd., a native legume from the Caatinga dry forest (Northeastern Brazil)
}

\author{
Diversidade de novas bactérias isoladas de nódulos de Erythrina velutina Willd., \\ uma leguminosa nativa da floresta seca "Caatinga” (Região Nordeste do Brasil)
}

\author{
Kelly Alexsandra Souza Menezes ${ }^{1}$, Gersika Fakirra de Oliveira Nunes ${ }^{1}$, Aline Araujo Sampaio ${ }^{1}$, \\ Aleksandro Ferreira da Silva², Layane Silva Barbosa de Souza ${ }^{1}$, Carlos Alberto Tuão Gava3 \\ Lindete Míria Vieira Martins ${ }^{1}$ and Paulo Ivan Fernandes-Júnior ${ }^{3, *}$
}

\author{
${ }^{1}$ Departamento de Tecnologia e Ciências Sociais, Universidade do Estado da Bahia, Juazeiro, BA, Brazil; \\ 2 Universidade Federal Rural de Pernambuco; Recife, PE, Brazil; \\ ${ }_{3}^{3}$ Embrapa Semiárido, BR 428, Km 152, Petrolina, PE, Brazil, CEP: 56302-970, CP 23. \\ (*E-mail: paulo.ivan@embrapa.br) \\ http://dx.doi.org/10.19084/RCA15050
}

Received/recebido: 2015.04.07

Accepted/aceite: 2015.08.10

\begin{abstract}
A B S T R A C T
This study aims to evaluate the phenotypical characteristics of bacterial isolates from mulungu (Erythrina velutina Willd.) nodules and determinate their Box-PCR fingerprinting. All bacteria were evaluated by the following phenotypic characteristics: growth rate, $\mathrm{pH}$ change, colony color and mucus production. The bacterial isolates able to re-nodulate the original host were also evaluated regarding its tolerance to increased salinity and different incubation temperatures, ability to growth using different carbon sources, intrinsic antibiotic resistance and "in vitro" auxin biosynthesis. The molecular fingerprints were set up using the Box-PCR technique and the isolates were clustered by their profiles. Among the 22 bacterial isolates obtained, eight were able to re-nodulate the original host. Among the nodule inducing isolates, some were tolerant to $1 \%$ of $\mathrm{NaCl}$ and $39^{\circ} \mathrm{C}$ and all of them metabolized the maltose, fructose, glucose, sucrose and arabinose, were resistant to rifampicin and produced auxin. The bacteria showed low genetic similarity among them and reference strains, which indicates the great genetic variability of the isolates. The results of this work are the first reports about the bacterial isolates able to nodulate this species. A more deep study of these bacteria may reveal the existence of isolates tolerant to environmental stresses and suitable as a future mulungu inoculant.
\end{abstract}

Keywords: Biological nitrogen fixation, inoculant, rhizobia, tree legumes.

\section{R E S U M O}

O objetivo desse estudo foi avaliar as características fenotípicas dos isolados de nódulos de mulungu (Erythrina velutina Willd.) e determinar seu fingerprinting molecular por meio de Box-PCR. Todas as bactérias foram avaliadas pelas seguintes características fenotípicas: tempo de crescimento, alteração de $\mathrm{pH}$, cor da colónia e produção de muco. As bactérias isoladas hábeis em renodular o hospedeiro original também foram avaliadas em relação à tolerância ao aumento da salinidade e da temperatura de incubação, capacidade de crescimento utilizando diferentes fontes de carbono, resistência intrínseca aos antibióticos e biossíntese de auxina "in vitro". O fingerprint molecular foi estabelecido usando a técnica Box-PCR e os isolados foram agrupados pelos perfis obtidos. Dos 22 isolados obtidos, oito foram hábeis em renodular o hospedeiro original. Entre eles, alguns foram tolerantes a $1 \%$ de $\mathrm{NaCl}$ e a $39^{\circ} \mathrm{C}$ e todos metabolizaram as fontes maltose, frutose, glicose, sacarose e arabinose, resistiram à rifampicina e produziram auxina. As bactérias isoladas mostraram baixa similaridade genética entre elas e as estirpes de referência, o que indica a grande variabilidade genética dos isolados. Os resultados deste trabalho constituem o primeiro relato sobre bactérias capazes de nodular esta espécie. O estudo mais aprofundado destas bactérias poderá revelar a existência de isolados tolerantes a stresses ambientais e adequados a serem utilizados como futuros inoculantes de mulungu.

Palavras-chave: Fixação biológica de azoto, inoculante, leguminosa arbórea, rizóbio. 


\section{INTRODUCTION}

The Fabaceae (Leguminosae) is one of the most diverse and abundant among the angiosperm families with three subfamilies: Mimosoideae, Faboideae (Papilionoideae) and Caesalpinioideae and represents approximately 18.000 species of about 650 genera (Souza and Lorenzi, 2008). In the "Caatinga", a biome that covers most part of the Brazilian northeastern region, about 127 genera and more than 600 species of this family are found (Zappi et al, 2015).

Erythrina is a pantropical genus harboring more than 100 species. The genus belongs to the Faboideae subfamily and Phaseoleae tribe (Sprent and Parsons, 2000). It is commonly used as an ornamental plant due to its attractive flowering and also because of its popular medicine (Sprent and Parsons, 2000; Lorenzi, 2002; Castro and Cavalcante, 2011).

This legumeis able to form root nodulesin symbiosis with diazotrophic organisms, collectively known as "rhizobia", which reduces atmospheric nitrogen to ammonia by means of the Biological Nitrogen Fixation (BNF) process (Moreira and Siqueira, 2006; Oldroyd et al., 2011). There are still few results evaluating the diversity and efficiency of rhizobia native to the Northeastern region of Brazil. Recent studies have shown that the legumes from Brazilian Semi-arid can associate themselves to a large variety of rhizobia (Teixeira et al., 2010; Freitas et al., 2014), which show increased symbiotic efficiency (Freitas et al., 2010).

Studies on the diversity of rhizobia that are associated with autochthonous plants from the Semiarid, as mulungu, for example, are still very scarce. The phenotypical and molecular characterization of the bacteria obtained from these plants may contribute to increase the knowledge about physiological features and taxonomic position of native rhizobia and make possible the selection of bacteria that presents adaptations to harsh edaphoclimatic conditions and diverse biotechnological applications. To our knowledge, there is no available data on the characterization of rhizobial isolates from mulungu.

To select efficient rhizobial strains for BNF, phenotypic characterization has been one of the most used methods for an initial classification
(Wolde-Meskel et al., 2004; Florentino et al., 2014) and may play an important role in the identification of rhizobial isolates. Phenotypic characterization is the basis of polyphasic taxonomy and, together with molecular techniques, has contributed to an improved understanding of the physiology and genetic diversity of rhizobia (Zerhari et al., 2000; Fall et al., 2008; Rasul et al., 2012). Among the molecular characterization techniques, fingerprinting by means of Box-PCR generated profiles have been used to examine the diversity of diazotrophic bacteria associated with the (Stocco et al., 2008; Costa et al., 2014; Torres-Júnior et al., 2014) and native species (Fernandes Júnior et al., 2013; Granada et al., 2014) from Brazil. This simple and low-cost technique allows the discrimination among several rhizobial isolates and reference strains, making possible a fast fingerprinting and selection of bacterial isolates. The aim of this study was to determine the phenotypic characteristics and molecular fingerprinting of Erythrina velutina Willd. rhizobial isolates from Brazilian semi-arid soils.

\section{MATERIAL AND METHODS}

A pot experiment was set up using $500 \mathrm{~mL}$ soil capacity pots. Four superficial soil samples (0-0.2 $\mathrm{m})$, two from Bahia state (municipality of Juazeiro) and two from Pernambuco state (municipalities of Lagoa Grande and Araripina) were taken in the field. The soil samples used for this trial were collected under Caatinga vegetation with different land uses. A subsample of each studied soil was examined for its chemical characteristics according to Embrapa (1997). The soil chemical characteristics and the area description are described in the Table 1. For the trap host experiment, the mulungu seeds were scarred by mechanical abrasion and superficially disinfected with ethanol at $96^{\circ} \mathrm{GL}$, sodium hypochlorite at $2 \%(\mathrm{w} / \mathrm{v})$ for 5 minutes and washed 10 times with sterile distilled water (SDW). The seeds were sown, six per pot, and thinned by two plants per pot, 20 days after germination. The plants received SDW according to necessity and grown for 88 days after which they were harvested and the nodules were detached from the roots.

For isolation purposes, the nodules were superficially disinfected with ethanol at $96^{\circ} \mathrm{GL}$ for 30 seconds, with sodium hypochloride at $2 \%(\mathrm{v} / \mathrm{v})$ for 5 minutes and eight washings in SDW (Vincent, 
Table 1 - Localization and characterization of the soils

\begin{tabular}{|c|c|c|c|c|c|c|c|c|c|c|c|c|c|c|c|c|}
\hline \multirow{3}{*}{ Soil } & \multirow{3}{*}{ Localization } & \multirow{3}{*}{ Municipality } & \multirow{3}{*}{ Description } & \multicolumn{13}{|c|}{ Chemical Characterization } \\
\hline & & & & $\begin{array}{c}\mathrm{pH} \\
\left(\mathrm{H}_{2} \mathrm{O}\right)\end{array}$ & $\underset{\left(\mathbf{m g} / \mathbf{d m}^{-3}\right)}{\mathbf{P}}$ & $\mathbf{A l}^{3+}$ & $\mathbf{M g}^{2+}$ & $\mathrm{Ca}^{2+}$ & $\mathbf{K}^{+}$ & $\mathrm{Na}^{+}$ & $\mathbf{H}^{+}+\mathbf{A l}^{3+}$ & $\begin{array}{c}\mathbf{S} \\
\text { (Bases) }\end{array}$ & CTC & \multirow{2}{*}{$\begin{array}{l}\text { MO } \\
\text { g/Kg }\end{array}$} & \multirow{2}{*}{$\begin{array}{r}\text { CE } \\
\text { dS } / \mathbf{m}\end{array}$} & \multirow{2}{*}{$\begin{array}{l}\mathrm{V} \\
\%\end{array}$} \\
\hline & & & & & & $\cdots$ & 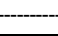 & - & --on & $\mathbf{m o l}_{\mathrm{c}} / \mathrm{dr}$ & & & 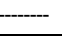 & & & \\
\hline $\begin{array}{l}\text { (1) Red- } \\
\text { Yellow } \\
\text { Oxisol } \\
\text { (LVA) }\end{array}$ & $\begin{array}{c}40^{\circ} 36^{\prime} 00^{\prime \prime} \mathrm{W} \\
7^{\circ} 29^{\prime} 00^{\prime \prime} \mathrm{S}\end{array}$ & Araripina-PE & Preserved area & 5.0 & 3.38 & 0.55 & 2.7 & 0.94 & 0.1 & 0.03 & 5.11 & 3.77 & 8.88 & 11.17 & 0.22 & 42 \\
\hline $\begin{array}{l}\text { (2) } \\
\text { Haplic } \\
\text { Vertisol } \\
\text { (VX) }\end{array}$ & $\begin{array}{c}40^{\circ} 25^{\prime} 27 \text { "W } \\
9^{\circ} 26^{\prime} 40^{\prime \prime} \mathrm{S}\end{array}$ & $\begin{array}{l}\text { Juazeiro- } \\
\text { BA }\end{array}$ & $\begin{array}{l}\text { Anthropized } \\
\text { area }\end{array}$ & 6.9 & 38.33 & 0.00 & 4.8 & 40.4 & 0.76 & 0.36 & 1.32 & 46.32 & 47.64 & 15.21 & 0.6 & 97 \\
\hline $\begin{array}{c}\text { (3) } \\
\text { Dystrophic } \\
\text { Red Ultisol } \\
\text { (PVd) }\end{array}$ & $\begin{array}{c}40^{\circ} 36^{\prime} 43 \text { "W } \\
9^{\circ} 31^{\prime} 46 \text { "S }\end{array}$ & $\begin{array}{l}\text { Juazeiro- } \\
\text { BA }\end{array}$ & Preserved area & 6.3 & 3.08 & 0.05 & 3.1 & 9.4 & 0.54 & 0.06 & 1.32 & 13.1 & 14.32 & 16.65 & 0.22 & 91 \\
\hline $\begin{array}{c}\text { (4) } \\
\text { Fluvic } \\
\text { Neosol (RU) }\end{array}$ & $\begin{array}{l}40^{\circ} 19 ' 5 \text { 'W } \\
09^{\circ} 04^{\prime} 16^{\prime \prime} \mathrm{S}\end{array}$ & $\begin{array}{l}\text { Lagoa Grande- } \\
\text { PE }\end{array}$ & $\begin{array}{c}\text { Area of riparian } \\
\text { vegetation under } \\
\text { recovery }\end{array}$ & 5.7 & 21.6 & 0.05 & 7.6 & 0.3 & 0.55 & 2.4 & 4.12 & 10.83 & 14.95 & 33.96 & 2.26 & 72 \\
\hline
\end{tabular}

1970) and, with the aid of pincers, macerated onto Petri dishes containing YMA medium with Congo Red. The dishes were incubated at $28^{\circ} \mathrm{C}$ in a growth chamber and the appearance of the characteristic rhizobial colonies was monitored daily. After that, the colonies were also inoculated on dishes containing YMA medium with bromothymol blue, incubated for their appropriate growth time and purified in the same medium. The bacteria were stored in YMA medium containing glycerol at 30\% $(\mathrm{w} / \mathrm{v})$ in a freezer at $-20^{\circ} \mathrm{C}$.

Nodulation capacity of the isolates for mulungu was examined in greenhouse conditions experiment using pots containing autoclaved sand as substrate. For this test, seeds were scarified, superficially disinfected and sown in $500 \mathrm{~mL}$ polyethylene pots. At the beginning three seeds per pot were sown. Thinning was carried out 20 days after emergence (DAE) and only one plant was left per pot. For the inoculation, the bacterial isolates were grown in liquid YM medium (Vincent, 1970) during the appropriate growth time for each isolate and $1 \mathrm{~mL}$ of broth culture was inoculated per seed at the sowing time and re-inoculated at 15 DAE. Besides the inoculation treatments with each isolate obtained from the mulungu nodules, a control treatment (not inoculated) was also included. The experiment was set with three replications in a completely randomized design up to 90 DAE when nodulation was evaluated. The characterization of all the obtained bacteria, was carried out to examine the further characteristics: alteration of the medium $\mathrm{pH}$ (acid, neutral or alkaline), growth time of the colonies (fast: up to three days; intermediate: four to five days and slow: over six days), colony color, type (viscous or floculous) and quantity (low or high) of mucus.

The isolates able to re-nodulate the host were assessed for other complementary phenotypic characteristics. Tolerance to salinity was examined by the bacterial growth in YMA medium supplemented with $\mathrm{NaCl}$ at 1 and $2 \%$ $(w / v)$ concentrations. Growth of the isolates at different temperatures was determined in solid YMA medium at incubation temperatures of 28 (control), 39 and $41^{\circ} \mathrm{C}$ in a growth chamber during the appropriate growth time for each isolates. The capacity of microbial isolates to metabolize different carbon sources was examined in modified YMA medium with mannitol substituted for arabinose, sodium acetate, maleic acid, malic acid, succinic acid, fructose, glucose, maltose, xylose and sucrose (Vetec Química Fina, Rio de Janeiro, Brazil) at $1 \%(\mathrm{w} / \mathrm{v})$.

Intrinsic antibiotics resistance was examined through plate diffusion method with impregnated discs (Bauer et al., 1966). The bacteria were previously cultivated at YM liquid medium during the time required for each isolate. The optic density of the culture broth was adjusted to O.D. $=0.5-0.6$ in a spectrophotometer (Multiskan GO, Thermo Scientific) at $560 \mathrm{~nm}$. The adjusted cell broth were inoculated at plate dishes containing YMA culture medium, spread with a Drygalsky loop and paper disks containing antibiotics were placed in the culture medium. The following antibiotics were used: streptomycin (10 $\mu \mathrm{g})$, rifampicin $(5 \mu \mathrm{g})$, neomycin $(30 \mu \mathrm{g})$, erythromycin $(15 \mu \mathrm{g})$, vancomycin $(30 \mu \mathrm{g})$, nalidixic acid (30 
$\mu \mathrm{g})$, gentamicin $(10 \mu \mathrm{g})$, ampicillin $(10 \mu \mathrm{g})$ and chloramphenicol (30 $\mu \mathrm{g}$ ) (Sensifar, São Paulo, Brazil). The sensibility or resistance of the bacterial isolates to the antibiotics was evaluated by the presence or the absence of a growth inhibition circle, respectively, surrounding the discs. The salt, temperature and intrinsic antibiotic resistance essays were conducted with three replications. The treatments with great differences among all replicates were repeated to be assured.

The colorimetric method described by Sarwar and Kremer (1995) was applied to quantify the auxin (indol acetic acid - IAA) production in YM culture medium. The bacteria were grown in YM medium, without the $\mathrm{pH}$ indicator, supplemented with $175 \mathrm{mM}$ of tryptophan (Vetec Química Fina, Rio de Janeiro, Brazil). The optic density of the broth culture was adjusted to O.D. $=0.5-0.6$ in a spectrophotometrically as described above. The adjusted broth cultures were centrifuged $(6000 \mathrm{~g}$ for $5 \mathrm{~min}$ ) and the supernatant was used for the colorimetric reaction with a Salkowski reagent (1.5:1 proportion). The samples were kept to react in the dark for 30 minutes and the IAA concentration was determined spectrophotometrically at 540 $\mathrm{nm}$. Quantification was carried out by comparing to a calibration curve obtained using synthetic IAA (Vetec Química Fina, Rio de Janeiro, Brazil). Besides the mulungu isolates, a Bradyrhizobium spp. (BR 2003) and a B. pachyrhizi (BR 3262) were used as reference strains. The IAA production data were submitted to analysis of variance using the Sisvar statistics package. The means were compared through the Scott-Knott means test $(p<0.01)$.

Molecular fingerprinting of the isolates was performed using the Box-PCR technique. For DNA extraction, the bacteria were grown in YM culture medium (Vincent, 1970) without the $\mathrm{pH}$ indicator for three days for bacteria with rapid growth and six days for bacteria with slow growth. The DNA was extracted with the commercial kit HiYield ${ }^{\mathrm{TM}}$ Genomic DNA Mini Kit (Real Biotech Corporation, Taipei, Taiwan) following the manufacturer instructions. For comparison, the rhizobial strains Rhizobium tropici (BR 322), Bradyrhizobium sp. (BR 5609), Ensifer fredii (BR 4007) and Burkholderia sabiae (BR 3405 and BR 3407) were used as reference strains. The reference strains were obtained from the "Johanna Döbereiner Diazothrofic Bacteria Culture Collection" of Embrapa Agrobiologia (Seropédica, RJ).
For the Box-PCR reaction, the A1 Box primer (CTACGGCAAGGCGACGCTGACG) was used (Versalovic et al., 1994). The PCR reaction was dimensioned for $25 \mu \mathrm{L}$ with a reaction buffer $(1 \mathrm{x})$, $\mathrm{MgCl}_{2}$ (3 mM), dNTPs (1.5 $\mu \mathrm{M}$ of each base), $2 \mu \mathrm{M}$ of the initiator and $1.25 \mathrm{U}$ of Taq DNA Polymerase, apart from approximately $50 \mathrm{ng}(1 \mu \mathrm{L})$ of the genomic DNA. The PCR was set up of an initial denaturation cycle at $94^{\circ} \mathrm{C}$ for 8 minutes, followed by 35 cycles of denaturation step at $94^{\circ} \mathrm{C}$ for 1 minute, annealing step at $53^{\circ} \mathrm{C}$ for 1 minute and extension step at $72^{\circ} \mathrm{C}$ for 8 minutes, completed with a final extension for 16 minutes (Hungria et al., 2008; Fernandes Júnior et al., 2013).

The PCR product was submitted to horizontal electrophoresis in agarose gel at $1.5 \%(\mathrm{w} / \mathrm{v})$ at $120 \mathrm{~V}$ for six hours. The gel was stained with ethidium bromide $(0.05 \% \mathrm{w} / \mathrm{v})$ and visualized with a photodocumentation system with UV light. The digital image of the gel was analyzed using the Bionumerics software version 7.0 (Applied Maths, Kortrijk, Belgium). The bacterial Box-PCR profiles were clustered applying the Pearson coefficient and the UPGMA clustering method was used to construct the similarity dendrogram.

\section{RESULTS}

The cultural characteristics of 22 isolates obtained from the mulungu nodules are described in Table 2. The bacteria showed various growth characteristics and most of them were fast growth. Besides these characteristics, there also was a predominance of isolates that acidify the medium $\mathrm{pH}$, produced high viscous mucus and cream-colored colonies. The 22 obtained isolates were tested in a greenhouse experiment and only eight of them (ESA 0068, ESA 0069, ESA 0070, ESA 0071, ESA 0072, ESA 0073, ESA 0074 e ESA 0075) were able to re-nodulate the mulungu plants and were selected for additional phenotypic and molecular assays. Among the eight bacteria that nodulated the original host in this study, half of them showed characteristics compatible with the isolates belonging to Bradyrhizobium sp. genus, such as increased $\mathrm{pH}$ and intermediate or slow growth. The other nodulating bacteria showed fast growth and acidified the culture medium, which are characteristics compatible with bacteria of the Rhizobium genus. 
Table 2 - Characterization of bacterial isolates from roots nodules of mulungu (Erythrina velutina Willd.) in YMA culture medium

\begin{tabular}{|c|c|c|c|c|c|c|c|}
\hline \multirow{2}{*}{ Isolates } & \multicolumn{5}{|c|}{ Characteristics of the isolated groups } & \multirow{2}{*}{ Nodulation } & \multirow{2}{*}{ Soil } \\
\hline & GT & pH & QM & $\mathrm{CC}$ & TM & & \\
\hline ESA 0068 & Fast & Neutral & High & Cream & Viscous & + & LVA \\
\hline ESA 0069 & Fast & Acid & High & Cream & Viscous & + & LVA \\
\hline ESA 0070 & Fast & Acid & High & Cream & Viscous & + & LVA \\
\hline ESA 0071 & Fast & Acid & High & Yellow & Viscous & + & $\mathrm{VX}$ \\
\hline ESA 0072 & Intermediate & Alkaline & Low & Cream & Viscous & + & $\mathrm{PVd}$ \\
\hline ESA 0073 & Slow & Alkaline & Low & Cream & Floculous & + & RU \\
\hline ESA 0074 & Slow & Alkaline & Low & Cream & Floculous & + & RU \\
\hline ESA 0075 & Slow & Alkaline & Low & Cream & Floculous & + & $\mathrm{RU}$ \\
\hline ESA 0077 & Fast & Neutral & High & Cream & Viscous & - & LVA \\
\hline ESA 0078 & Fast & Neutral & High & Cream & Viscous & - & LVA \\
\hline ESA 0079 & Fast & Acid & High & Cream & Viscous & - & LVA \\
\hline ESA 0080 & Fast & Acid & High & Cream & Viscous & - & LVA \\
\hline ESA 0081 & Fast & Neutral & High & Yellow & Viscous & - & LVA \\
\hline ESA 0082 & Fast & Neutral & High & Cream & Viscous & - & LVA \\
\hline ESA 0083 & Fast & Acid & High & Cream & Viscous & - & LVA \\
\hline ESA 0084 & Fast & Acid & High & Yellow & Viscous & - & VX \\
\hline ESA 0085 & Fast & Neutral & High & Cream & Viscous & - & VX \\
\hline ESA 0086 & Fast & Acid & High & Cream & Viscous & - & VX \\
\hline ESA 0087 & Fast & Acid & High & Cream & Viscous & - & VX \\
\hline ESA 0088 & Intermediate & Neutral & Low & Cream & Floculous & - & VX \\
\hline ESA 0089 & Intermediate & Acid & High & Cream & Viscous & - & VX \\
\hline ESA 0090 & Fast & Acid & Low & Cream & Viscous & - & RU \\
\hline
\end{tabular}

${ }^{1} \mathrm{GT}$ - Growth Time (Fast $\leq 3$ days, Intermediate between 4-5 days and Slow > 6 days); medium pH (Acid, Neutral, Alkaline ); QM - Quantity of Mucus (High and Low); CC - Colony Color (Yellow and Cream); TM - Type of Mucus (Viscose and Floculose).

The eight isolates were tested for their growth in different concentrations of $\mathrm{NaCl}$ and incubation temperatures (Table 3). None of these isolates were able to growth in medium supplemented with $2 \%$ of $\mathrm{NaCl}$. The isolates ESA 0068, ESA 0069 and ESA 0070 were able to growth in culture medium supplemented with $1 \%$ of $\mathrm{NaCl}$ whereas the remaining isolates (ESA 0071, ESA 0072, ESA 0073, ESA 0074 and ESA 0075) did not grow in the same $\mathrm{NaCl}$ concentration. In relation to growth at increased temperatures it was found that none of the tested isolates grew when incubated at $41^{\circ} \mathrm{C}$. The isolates ESA 0068, ESA 0069, ESA 0070, ESA 0071, ESA 0072, ESA 0074 and ESA 0075 grew at an incubation temperature of $39^{\circ} \mathrm{C}$, whereas the isolate ESA 0073 showed more sensitivity growing only in the control treatment $\left(28^{\circ} \mathrm{C}\right)$.

All isolates were able to metabolize maltose, fructose, glucose, sucrose and arabinose as carbon sources. The more limiting sources were malic acid, maleic acid, sodium acetate and succinic acid, which did not permit the growth of five among the eight isolates studied. Regarding the growth capacity of the bacteria in different $C$ sources, isolates ESA 0068, ESA 0069 and ESA 0070 were the most versatile and grew in all sources tested. Isolates ESA 0071, ESA 0072 and ESA 0074, which showed distinct 
Table 3 - Characterization of bacterial isolates from roots nodules of mulungu (Erythrina velutina Willd.) in YMA culture medium

\begin{tabular}{|c|c|c|c|c|c|c|c|c|}
\hline \multirow{2}{*}{ Characteristics } & \multicolumn{8}{|c|}{ Isolates } \\
\hline & $\begin{array}{l}\text { ESA } \\
0068\end{array}$ & $\begin{array}{l}\text { ESA } \\
0069\end{array}$ & $\begin{array}{l}\text { ESA } \\
0070\end{array}$ & $\begin{array}{l}\text { ESA } \\
0071\end{array}$ & $\begin{array}{l}\text { ESA } \\
\text { 0072 }\end{array}$ & $\begin{array}{l}\text { ESA } \\
0073\end{array}$ & $\begin{array}{l}\text { ESA } \\
\text { 0074 }\end{array}$ & $\begin{array}{l}\text { ESA } \\
0075\end{array}$ \\
\hline \multicolumn{9}{|l|}{ Tolerance to $\mathrm{NaCl}^{1}$} \\
\hline $1 \%$ & + & + & + & - & - & - & - & - \\
\hline $2 \%$ & - & - & - & - & - & - & - & - \\
\hline \multicolumn{9}{|c|}{ Tolerance to increased temperatures ${ }^{1}$} \\
\hline $39^{\circ} \mathrm{C}$ & + & + & + & + & + & - & + & + \\
\hline $41^{\circ} \mathrm{C}$ & - & - & - & - & - & - & - & - \\
\hline \multicolumn{9}{|c|}{ Use of different carbon sources ${ }^{1}$} \\
\hline Malic acid & + & + & + & - & - & - & - & - \\
\hline Maleic acid & + & + & + & - & - & - & - & - \\
\hline Sodium acetate & + & + & + & - & - & - & - & - \\
\hline Succinic acid & + & + & + & - & - & - & - & - \\
\hline Maltose & + & + & + & + & + & + & + & + \\
\hline Fructose & + & + & + & + & + & + & + & + \\
\hline Glucose & + & + & + & + & + & + & + & + \\
\hline Sucrose & + & + & + & + & + & + & + & + \\
\hline Arabinose & + & + & + & + & + & + & + & + \\
\hline Xylose & + & + & + & - & - & + & - & + \\
\hline \multicolumn{9}{|c|}{ Intrinsic antibiotic resistance $^{2}$} \\
\hline Streptomycin & + & + & + & + & - & - & - & - \\
\hline Rifampicin & + & + & + & + & + & + & + & + \\
\hline Neomycin & + & - & - & - & - & + & + & + \\
\hline Erythromycin & + & + & + & - & - & - & + & + \\
\hline Vancomycin & + & + & + & - & - & - & + & - \\
\hline Nalidixic acid & + & + & + & + & - & - & + & + \\
\hline Gentamicin & - & - & - & - & - & - & - & - \\
\hline Ampicillin & + & + & + & - & + & + & + & - \\
\hline Chloramphenicol & + & - & + & + & - & + & + & - \\
\hline
\end{tabular}


cultural characteristics, were not able to grow in five among ten carbon sources, which were: malic acid, maleic acid, sodium acetate, succinic acid and xylose. The evaluation of the intrinsic antibiotic resistance showed that gentamicin was found to be the antibiotic that most restricted bacterial growth. On the other hand, rifampicin did not limit growth of any of the tested bacteria. The isolate ESA 0068 was the most tolerant, being resistant to eight of the nine antibiotics used.

The ESA 0068, ESA 0069 and ESA 0070 bacteria showed the same culture characteristics in terms of growth time, colony color, production and type of mucus, and were among the most tolerant ones to heat $\left(39^{\circ} \mathrm{C}\right)$, salt $(1 \% \mathrm{NaCl})$ and antibiotics (six of the nine tested antibiotics) and growth in the tested carbon sources.

All the isolates and reference strains produced IAA in the culture medium supplemented with L-tryptophan, although there were some variation among the strains tested in the produced concentrations (Figure 1). The isolates ESA 0071

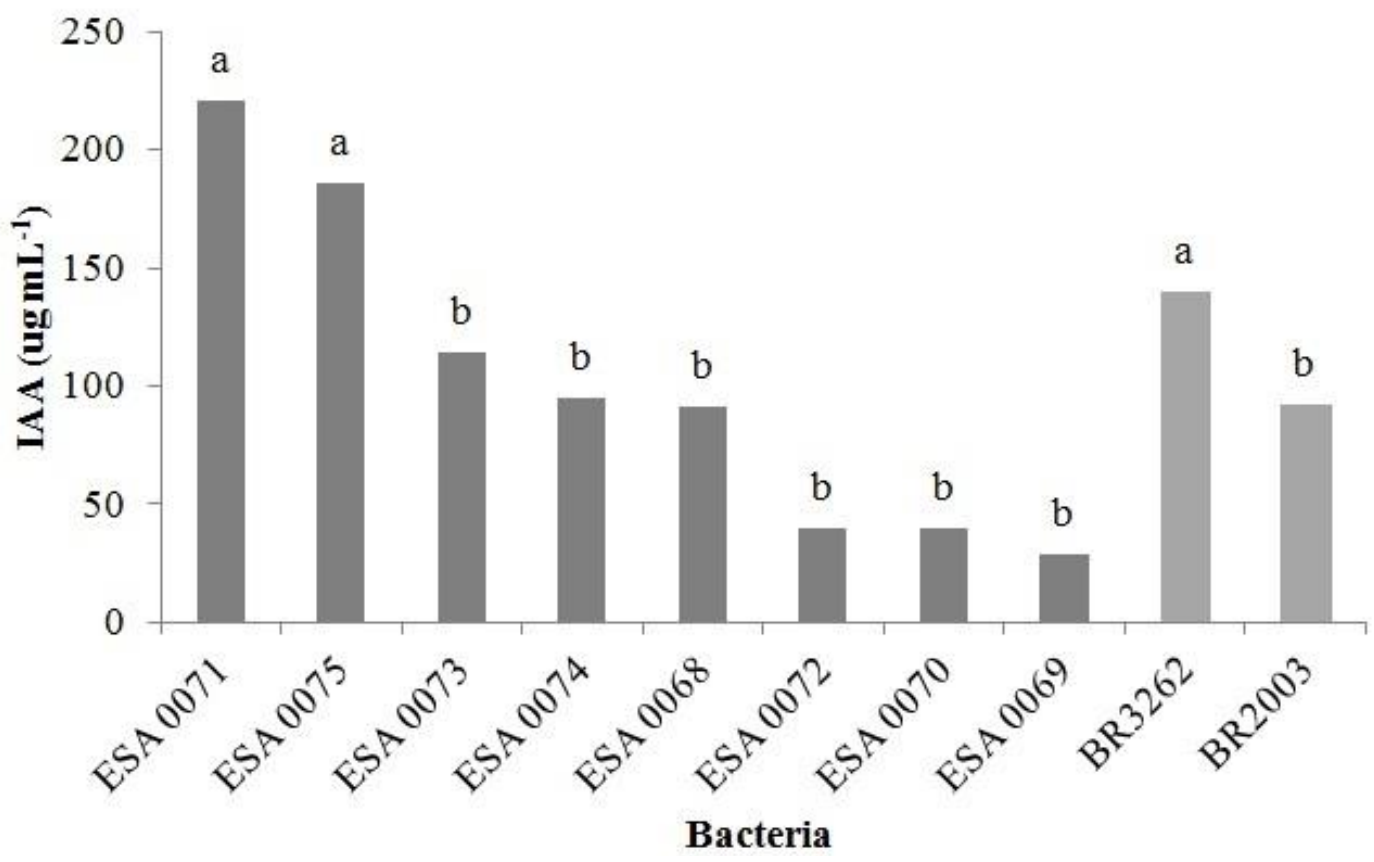

Figure 1 - Production of indoleacetic acid (IAA) by rhizobial isolates from mulungu root nodules (Erythrina velutina Willd.).
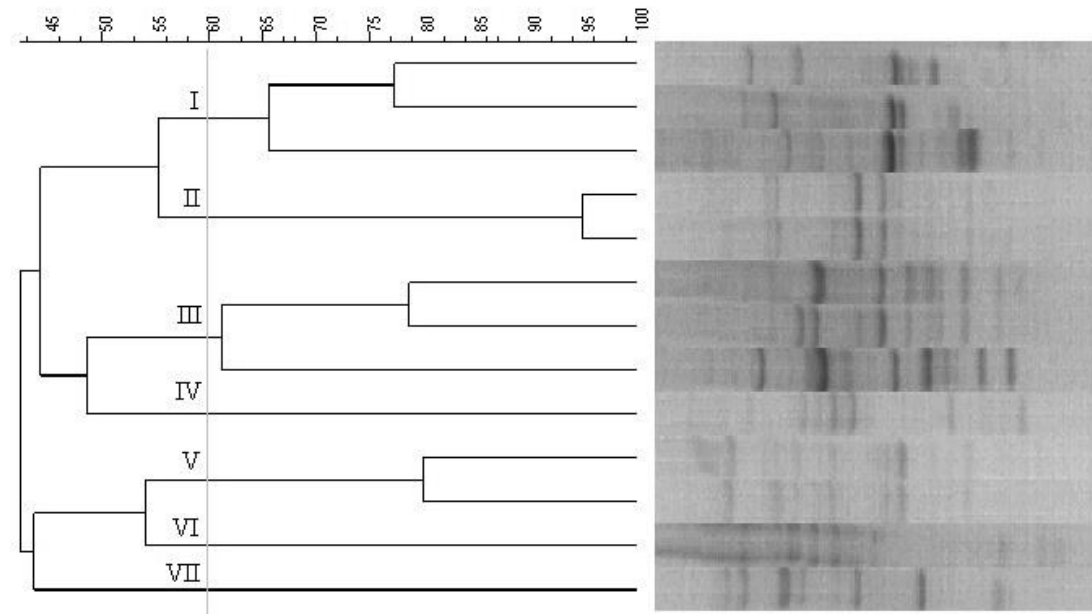

ESA 0071

R. tropici (BR 322)

Bradyrhizobium sp. (BR 5609)

ESA 0070

ESA 0068

Bu. sabiae (BR 3405)

Bu. sabiae (BR 3407)

E. fredii (BR 4007)

ESA 0073

ESA 0075

ESA 0074

ESA 0072

ESA 0069

Figure 2 - Similarity dendrogram based on the Box-PCR profiles of eight rhizobia isolated from mulungu (Erythrina velutina Willd.) and five rhizobial reference strains. Dendrogram was constructed applying the Pearson coefficient and UPGMA clustering method. 
and ESA 0075 stood out in this evaluation because these bacteria differed significantly from the other mulungu isolates and did not differed only from the BR 3262 reference strain. The isolates ESA 0073, ESA 0074, ESA 0068, ESA 0072, ESA 0070 and ESA 0069 did not differ from the reference strain BR 2003.

The analysis of the similarity dendrogram showed that all the bacteria isolated from the mulungu and the reference strains had about $40 \%$ of similarity (Figure 2). At $60 \%$ of the similarity, the formation of distinct clusters can be observed. Clusters I encompasses the isolate ESA 0071 and the strains of Rhizobium tropici and Bradyrhizobium sp. The isolates ESA 0070 and ESA 0068 belonged to the cluster II, while cluster III was composed only by reference strains, with both Burholderia sabiae strains and Ensifer fredii. The cluster $\mathrm{V}$ was also formed only by two bacterial mulungu isolates (ESA 0074 and ESA 0075). Clusters IV, VI and VII were formed only by one bacteria isolated from mulungu root-nodule.

\section{DISCUSSION}

The mulungu isolates showed different growth characteristics ranging from fast to slow. The most of fast growing bacteria acidified the $\mathrm{pH}$ of the culture medium and showed an increased production of exopolysaccharides whereas the isolates that showed slow growth alkalinized the $\mathrm{pH}$ of the medium and had low mucus production. Recently Freitas et al. (2014) have observed that all isolates obtained from Mimosa tenuiflora and $M$. paraibana also presented fast growth. Furthermore, bacteria that acidified or did not modify the medium $\mathrm{pH}$ and had low to average mucus production were found. Evaluating phenotypic characteristics of bacterial isolates from Gliricidia sepium in Brazil, Florentino et al. (2014) also reported that all isolates had fast growing, showed high mucus production and the majority were able to acidify the medium.

Among the 14 non-nodulating bacteria, 12 showed fast growth and acidification of the medium. The increased percentage of bacteria which are not able to re-nodulate the original host species is commonly found in studies of bacteria isolation from nodules of species in tropical climates (Lima et al., 2012). This incapacity may occur due to the loss of plasmids that carry the symbiotic genes during the successive cultivations in the process of isolation, purification and storage (Garcia de los Santos, 1996). For tree species, isolation of nonsymbiotic bacteria that co-inhabit the nodules, together with the rhizobia may also occur, as is described in the literature (Muresu et al., 2008; Shiairashi et al., 2010). These non-symbiotic organisms, because they take less time to appear in culture medium, occupy the Petri dishes more rapidly, which does not permit the observation of isolates that appear lately (Ourarhi et al., 2011).

Recent studies on phenotypic characteristics of isolates from tropical arboreal legumes have shown the existence of nodulating bacteria with characteristics that are compatible with those of the Rhizobium and Bradyrhizobium genera and equivalent frequencies between these phenotypic groups were observed (Gehlot et al., 2012), i.e., the predominance of fast growth bacteria which, acidify the medium $\mathrm{pH}$ (Freitas et al., 2014) or the predominance of slow growth bacteria with an alkaline reaction in the culture medium (Baraúna et al., 2014).

In studies examining nodulation of Millettia pinnata, an arboreal legume that also belongs to the Faboideae subfamily, Rasul et al. (2012) obtained half of the isolates of intermediate growth while in the studies of Arpiwi et al. (2013) slow growth bacteria predominated. These characteristics seem to be common in isolates that nodulate the Faboideae tree legumes since the current study also found characteristics of intermediate growth (ESA 0072) and slow growth (ESA 0073, ESA 0074 and ESA 0075), nodulating mulungu.

Three isolates (ESA 0068, ESA 0069 and ESA 0070) showed tolerance to an increased concentration of salt in culture medium, and in addition to these, the strains ESA 0071, ESA 0072, ESA 0074 and ESA 0075 were resistant to a temperature of $39^{\circ} \mathrm{C}$. Rhizobia of tree legumes that are tolerant to increased salinity and temperature have already been documented in other studies (Zerhari et al., 2000; Fterich et al., 2011; Shetta et al., 2011; Rasul et al., 2012; Arpiwi et al., 2013; Florentino et al., 2014). High tolerance to salinity and temperature is an important characteristic for the survival of rhizobia in environmentally unfavorable conditions. The fact that the majority of the bacteria from this study grow at $39^{\circ} \mathrm{C}$ may be related to their adaptation to edaphoclimatic conditions of the Semi-arid.

All the isolates tested were able to metabolize 
different carbon sources, which demonstrate the increased metabolic versatility of these bacteria. Arpiwi et al. (2013) verified that in relation to the use of different carbon sources, the majority of the isolates obtained from Millettia pinnata showed growth in medium containing glucose and arabinose and a considerable number did not grow in medium containing sucrose. The use of a greater variety of carbon sources by the bacterial isolates may constitute a characteristic of the adaptation to the different environmental conditions that are influenced by the root exudates of the hosts (Shetta et al., 2011).

Regarding the intrinsic antibiotics resistance, all isolates showed tolerance to rifampicin and susceptibility to gentamicin. In a study that examined rhizobia obtained from Centrolobium tomentosum nodules, Pagano (2008) found that the fast growing isolates were tolerant to streptomycin, chloramphenicol and ampicillin. These results are similar to those found in the present study for fast growth mulungu bacteria (ESA 0068, ESA 0069, ESA 0070 and ESA 0071) which were also tolerant to these antibiotics. At the same study, the author observed that the slow growing isolates showed less tolerance to streptomycin. In our study, the isolates (ESA 0073, ESA 0074 and ESA 0075) are slow growers and were also more susceptible to this antibiotic.

Furthermore, the three isolates that showed increased adaptation to high temperatures, salinity and antibiotics (ESA 0069, ESA 0070 and ESA 0068) are fast growing isolates. Other authors also confirmed the same tolerance characteristics of bacteria with the same growth characteristic (Zerhari et al., 2000; Fall et al., 2008; Rasul et al., 2012), which indicates that the studied mulungu isolates show a potential for inoculation in the semi-arid regions because they are well adapted to the typical stress conditions of these soils.

The capacity of IAA synthesis of rhizobia from tree species has already been documented in the literature. Manasilla et al. (2007), who studied rhizobia obtained from the nodules of the tree legumes Acacia auriculaformis Cunn., A. angium Willd., Milletia leucantha Kurz., Pterocarpus indicus Willd. and Xylia xylocarpa Taub. from Thailand, found that only four isolates were capable of producing IAA, being two from $A$. auriculiformis, one from $P$. indicus and one from $X$. xilocarpa. Rasul et al. (2012), who examined IAA production of 29 rhizobia, observed that the majority did not show the capacity to produce this phytohormone because only seven synthesized IAA. The results of the present study indicate that at least one isolate of fast growth (ESA 0071) and one isolate of slow growth (ESA 0075) produced IAA quantities that are only produced by strain BR 3262. In addition to the capacity of nodulating and fixing $N$, the results indicate that these bacteria show complementary mechanisms for increase the plant growth and may positively influence the development and establishment of mulungu in the field.

When examining the genetic similarity between the mulungu isolates and reference strains, it is possible to observe that these bacteria show around $40 \%$ of similarity, which indicates that mulungu isolates are not closely related to the reference strains. In this study, the isolate that showed the largest similarity with any reference strain was the isolate of fast growth ESA 0071, which showed about $77 \%$ of similarity with the $R$. tropici strain BR 322. The large genetic variability of the rhizobial isolates from tree legumes from the Brazilian Semiarid was already showed to other species, such as the Mimosa spp. (Teixeira et al., 2010; Freitas et al. 2014) and the data of the present study corroborate the reports already published.

The Box-PCR technique is an easy and low cost technique that has been recently used in several studies to examine genetic variability of nitrogenfixing bacteria obtained from different hosts. Among the cultivated species, studies conducted in Brazil have already examined the genetic variability of rhizobia of legumes such as pigeonpea (Costa et al., 2014), peanuts (Lyra et al., 2013; TorresJúnior et al., 2014), common beans (Stocco et al., 2008), among others. This technique is also used to examine the variability of strains isolated from native plants such as bromeliad (Giongo et al., 2013), wild rice (Fernandes Júnior et al., 2013) and legumes (Granada et al., 2014). The results obtained in the present study, demonstrate its applicability and indicate that this technique can be used with rhizobia of other native tree legumes.

The results of the present study indicate that mulungu shows effective rhizobial symbionts in the Brazilian Semi-arid region. Complementary studies examining the taxonomic positioning and their symbiotic efficiency will be important to demonstrate the biotechnological potential of these isolates. 


\section{CONCLUSIONS}

The isolates of rhizobia obtained from mulungu (Erythrina velutina) nodules show various phenotypic characteristics and low genetic similarity with the rhizobia reference strains that were used, which indicates that we can be dealing with still unknown species.

\section{ACKNOWLEDGEMENTS}

To "Coordenação de Aperfeiçoamento de Pessoal de Nivel Superior" (CAPES) and to the "Conselho Nacional de Desenvolvimento Científico e Tecnológico" (CNPq) by the granted scholarships. To "Universidade do Estado da Bahia" and to "Embrapa Semiárido" for their financial assistance and infrastructure.

\section{REFERENCES}

Arpiwi, N.L.; Yan, G.; Barbour, E.L.; Plummer, J.A. and Watkin, E. (2013) - Phenotypic and genotypic characterisation of root nodule bacteria nodulating Millettia pinnata (L.) Panigrahi, a biodiesel tree. Plant and Soil, vol. 367, n. 1-2, p. 363-377. http://dx.doi.org/10.1007/s11104-012-1472-4

Baraúna, A.C.; Silva, K.; Pereira, G.M.D.; Kaminski, P.E.; Perin, L. and Zilli, J.E. (2014) - Diversity and nitrogen fixation efficiency of rhizobia isolated from nodules of Centrolobium paraens. Pesquisa Agropecuária Brasileira, vol.49, n.4, p. 296-305. http://dx.doi.org/10.1590/S0100-204X2014000400008

Bauer, A.W.; Kirby, W.M.M.; Sherris, J.C. and Turck, M. (1966) - Antibiotic susceptibility testing by it standardized disk method. American Journal of Clinical Pathology, vol. 45, n. 4, p. 493-496.

Castro, A.S. and Cavalcante, A. (2011) - Flores da Caatinga. Instituto Nacional do Semiárido, Campina Grande, $116 \mathrm{p}$.

Costa, F.M.; Schiavo, J.A.; Brasil, M.S.; Leite, J.; Xavier, G.R. and Fernandes Júnior, P.I. (2014) - Phenotypic and molecular fingerprinting of fast growing rhizobia of field-grown pigeon pea from the eastern edge of the Brazilian Pantanal. Genetics and Molecular Research, vol. 13, n. 1, p. 469-482. http://dx.doi.org/10.4238/2014. January.21.16

Embrapa (1997) - Manual de Métodos de Análises de solo. 2ª ed. Rio de Janeiro, Ministério da Agricultura, Pecuária e Abastecimento, $212 \mathrm{p}$.

Fall, D.; Diouf, D.; Ourarhi, M.; Faye, A.; Abdelmoumen, H.; Neyra, M.; Sylla, S.N.; Missbah, E.L. and Idrissi, M. (2008) - Phenotypic and genotypic characteristics of Acacia senegal (L.) Willd. root-nodulating bacteria isolated from soils in the dryland part of Senegal. Letters in Applied Microbiology, vol. 47, n. 2, p. 85-97. http://dx.doi.org/10.1111/j.1472-765X.2008.02389.x

Fernandes Júnior, P.I.; Pereira, G.M.D.; Perin, L.; Silva, L.M.; Baraúna, A.C.; Alves, F.M.; Passos, S.R. and Zilli, J.E. (2013) - Diazotrophic bacteria isolated from wild rice Oryza glumaepatula (Poaceae) in the Brazilian Amazon. Revista de Biologia Tropical, vol. 61, n. 2, p. 991-999.

Florentino, L.A.; Rezende, A.V.; Mesquita, A.C.; Lima, A.R.S.; Marques, D.J. and Miranda, J.M. (2014) Diversidade e potencial de utilização dos rizóbios de nódulos de Gliricidia sepium. Revista de Ciências Agrárias, vol. 37, n. 3, p. 320-328.

Freitas, A.D.S.; Sampaio, E.V.S.B.; Santos, C.E.R.S and Silva, A.F. (2010) - Biological nitrogen fixation in tree legumes of the brazilian semi-arid Caatinga. Journal of Arid Environments, vol. 74, p. 344-349. http://dx.doi. org/10.1016/j.jaridenv.2009.09.018

Freitas, A.D.S.; Borges, W.L.; Andrade, M.M.M.; Sampaio, E.V.S.B.; Santos, C.E.R.S.; Passos, S.R.; Xavier, G.R.; Mulato, B.M. and Lyra, M.C.C.P. (2014) - Characteristics of nodule bacteria from Mimosa spp. grown in soils of the Brazilian semiarid region. African Journal of Microbiology Research, vol. 8, n. 8, p. 788-796. http://dx.doi.org/10.5897/AJMR2013.6518

Fterich, A.; Mahdhi, M.; Caviedes, M.A.; Pajuelo, E.; Rivas, R.; Rodriguez-Llorente, I.D. and Mars, M. (2011) - Characterization of root-nodulating bacteria associated to Prosopis farcta growing in the arid regions of Tunisia. Archives of Microbiology, vol. 193, n. 6, p. 385-397. http://dx.doi.org/10.1007/s00203-011-0683-z

García de los Santos, A.; Brom, S. and Romero, D. (1996) - Rhizobium plasmids in bacteria-legume interactions. World Journal of Microbiology \& Biotechnology, vol. 12, n. 2, p. 119-125. http://dx.doi.org/10.1007/BF00364676

Gehlot, H.S.; Panwar, D.; Tak, N.; Tak, A.; Sankhla, I.S.; Poonar, N.; Parihar, R.; Shekhawat, N.S.; Kumar, M.; Tiwari, R.; Ardley, J.; James, E.K. and Sprent, J.I. (2012) - Nodulation of legumes from the Thar desert of 
India and molecular characterization of their rhizobia. Plant and Soil, vol. 357, n. 1-2, p. 227-243. http:// dx.doi.org/1007/s11104-012-1143-5

Giongo, A.; Beneduzi, A.; Gano, K.A.; Vargas, L.K.; Utz, L.R.P. and Passaglia, L.M.P. (2013) - Characterization of plant growth-promoting bacteria inhabiting Vrisea gigantea Gaud, and Tillandsia aeranthos (Loiseleur) L. B. Smith (Bromeliacea). Biota Neotropica, vol. 13, n. 3, p. 80-85. http://dx.doi.org/10.1590/S167606032013000300010

Granada, C.E.; Strochein, M.; Vargas, L.K.; Bruxel, M.; Sá, E.L.S. and Passaglia, L.M.P. (2014) - Genetic diversity and symbiotic compatibility among rhizobial strains and Desmodium incanum and Lotus spp. plants. Genetics and Molecular Biology, vol. 37, n. 2, p. 396-405. http://dx.doi.org/10.1590/S1415-47572014000300012

Hungria, M.; Chueire, L.M.O.; Menna, P. and Bangel, E.V. (2008) - Caracterização genética de rizóbios e outras bactérias diazotróficas e promotoras do crescimento de plantas por BOX-PCR. Londrina, Embrapa Soja, 12 p. (Embrapa Soja. Comunicado Técnico, 290).

Lima, A.A.; Fernandes Júnior, P.I.; Passos, S.R.; Paulo, F.S.; Nosoline, S.M.; Faria, S.M.; Guerra, J.G.M.; Rumjanek, N.G. and Xavier, G.R. (2012) - Diversidade e capacidade simbiótica de rizóbios isolados de nódulos de Mucuna-Cinza e Mucuna-Anã. Revista Brasileira de Ciência do Solo, vol. 36, n. 2, p. 337-348. http://dx.doi.org/10.1590/S0100-06832012000200003

Lorenzi, H. (2002) - Árvores brasileiras: manual de identificação e cultivo de plantas arbóreas nativas do Brasil. $4^{a}$ ed. Plantarum, Nova Odessa, $352 \mathrm{p}$.

Lyra, M.C.C.P.; Freitas, A.D.S.;Silva, T.A. and Santos, C.E.R.S. (2013)- Phenotypic and molecular characteristics of rhizobia isolated from nodules of peanut (Arachis hypogaea L.) grown in Brazilian Spodosols. African Journal Biotechnology, vol. 12, n. 17, p. 2147-2156. http://dx.doi.org/10.5897/AJB11.1574

Manassila, M.; Nuntagij, A.; Kotepong, S.; Boonkerd, N. and Teaumroong, N. (2007) - Characterization and monitoring of selected rhizobial strains isolated from tree legumes in Thailand. African Journal Biotechnology, vol. 6, n. 12, p. 1393-1402.

Moreira, F.M.S. and Siqueira, J.O. (2006) - Microbiologia e Bioquímica do Solo. 2aㅡ ed. UFLA, Lavras, 729 p.

Muresu, R.; Polone, E.; Sulas, L.; Baldan, B.; Tondello, A.; Delogu, G.; Cappuccinelli, P.; Alberghini, S.; Benhizia, Y.; Benhizia, H.; Benguedouar, A.; Mori, B.; Calamassi, R.; Dazzo, F.B. and Squartini, A. (2008) - Coexistence of predominantly nonculturable rhizobia with diverse, endophytic bacterial taxa within nodules of wild legumes. FEMS Microbiology Ecology, vol. 63, n. 3, p. 383-400. http://dx.doi.org/10.1111/ j.1574-6941.2007.00424.x

Oldroyd, G.E.; Murray, J.D.; Poole, P.S. and Downie, J.A. (2011) - The rules of engagement in the legumerhizobial symbiosis. Annual Review of Genetics, vol. 45, p. 119-144. http://dx.doi.org/10.1146/annurevgenet-110410-132549

Ourarhi, M.; Abdelmoumen, H.; Guerrouj, K.; Benata, H.; Muresu, R.; Squartini, A. and El Idrissi, M.M. (2011) - Colutea arborescens is nodulated by diverse rhizobia in Eastern Morocco. Archives of Microbiology, vol. 193, n. 2, p. 115-124. http://dx.doi.org/10.1007/s00203-010-0650-0

Pagano, M.C. (2008) - Rhizobia associated with neotropical tree Centrolobium tomentosum used in riparian restoration. Plant Soil and Environment, vol. 11, p. 498-508.

Rasul, A.; Amalra, D.L.; Kumar, G.P.; Grover, M. and Venkateswarlu, B. (2012) - Characterization of rhizobial isolates nodulating Millettia pinnata in India. FEMS Microbiology Letters, vol. 336, n. 2, p. 148-158. http:// dx.doi.org/10.1111/1574-6968.12001

Sarwar, M. and Kremer, R.J. (1995) - Determination of bacterially derived auxins using a microplate method. Letters in Applied Microbiology, vol. 20, n. 5, p. 282-285. http://dx.doi.org/10.1111/j.1472-765X.1995.tb00446.x

Shetta, N.D.; Al-Shaharani, T.S. and Abdel-Aal, M. (2011) - Identification and characterization of Rhizobium associated with woody legume trees grown under Saudi Arabia condition. American-Eurasian Journal of Agricultural \& Environmental Sciences, vol. 10, n. 3, p. 410-418.

Shiraishi, A.; Matsushita, N. and Hougetsu, T. (2010) - Nodulation in black locust by the Gammaproteobacteria Pseudomonas sp. and the Betaproteobacteria Burkholderia sp. Systematic and Applied Microbiology, vol. 33, n. 5, p. 269-274. http://dx.doi.org/10.1016/j.syapm.2010.04.005

Souza, V.C. and Lorenzi, H. (2008) - Botânica sistemática: guia ilustrado para identificação das famílias de Fanerógamas nativas e exóticas no Brasil, baseado em APG II. 2ª ed. Instituto Plantarum, Nova Odessa, SP, $704 \mathrm{p}$.

Sprent, J.I. and Parsons, R. (2000) - Nitrogen fixation in legume and non-legume trees. Field Crops Research, 
vol. 65, n. 2, p. 183-196. http://dx.doi.org/10.1016/S0378-4290(99)00086-6

Stocco, P.; Santos, J.C.P..; Vargas, V.P. and Hungria, M. (2008) - Avaliação da biodiversidade de rizóbios simbiontes do feijoeiro (Phaseolus vulgaris L.) em Santa Catarina. Revista Brasileira de Ciência do Solo, vol. 32, n. 3, p. 1107-1120. http://dx.doi.org/10.1590/S0100-06832008000300019

Teixeira, F.C.P.; Borges, W.L.; Xavier, G.R. and Rumjanek, N.G. (2010) - Characterization of indigenous rhizobia from Caatinga. Brasilian Journal of Microbioloy, vol. 41, n. 1, p. 201-208. http://dx.doi.org/10.1590/ S1517-83822010000100029

Torres-Júnior, C.V.; Leite, J.; Santos, C.E.R.S.; Fernandes-Júnior, P.I.; Zilli, J.E.; Rumjanek, N.G. and Xavier, G.R. (2014) - Diversity and symbiotic performance of peanut rhizobia from Southeast region of Brazil. African Journal of Microbiology Research, vol. 8, n. 6, p. 566-577. http://dx.doi.org/10.5897/AJMR2013.5883

Versalovic, J.; Schneider, M.; De Bruijn, F.J. and Lupski, J.R. (1994) - Genomic fingerprinting of bacteria using repetitive sequence-based polymerase chain reaction. Methods in Molecular and Cellular Biology, vol. 5, p. 25-40.

Vincent, J.M. (1970) - A manual for the practical study of root nodule bacteria. IBP Handbook, n. 15, Blackwell, Oxford, $164 \mathrm{p}$.

Wolde-Meskel, E.; Berg, T.; Peters, N.K. and Frostegård, Å. (2004) - Nodulation status of native woody legumes and phenotypic characteristics of associated rhizobia in soils of southern Ethiopia. Biology and Fertility of Soils, vol. 40, n. 1, p. 55-66. http://dx.doi.org/10.1007/s00374-004-0743-5

Zappi, D.C.; Filardi, F.L.R.; Leitman, P.; Vinícius, C.S.; Bruno, M.T.W.; José, R.P.; Marli, P.M.; Queiroz, L.P.; Cavalcanti, T.B.; Mansano, V.F. and Forzza, R.C. (2015) - Growing knowledge: an overview of Seed Plant diversity in Brazil. Rodriguésia, vol. 66, n.4, p. 1085-1113. http://dx.doi.org/10.1590/2175-7860201566411

Zerhari, K.; Aurag, J.; Khbaya, B.; Kharchaf, D. and Filali-Maltouf, A. (2000) - Phenotypic characteristics of rhizobia isolates nodulating Acacia species in the arid and Saharan regions of Morocco. Letters in Applied Microbiology, vol. 30, n. 5, p. 351-357. http://dx.doi.org/10.1046/j.1472-765x.2000.00730.x 